medRxiv preprint doi: https://doi.org/10.1101/2021.04.01.21254397; this version posted April 5, 2021. The copyright holder for this preprint

(which was not certified by peer review) is the author/funder, who has granted medRxiv a license to display the preprint in perpetuity.

This article is a US Government work. It is not subject to copyright under 17 USC 105 and is also made available for use under a CCO license.

\title{
HBA Copy Number and Kidney Disease Risk among Black Americans: a Longitudinal Cohort Study
}

A. Parker Ruhl, MD, MHS ${ }^{1,2}$, Neal Jeffries, $P^{2} D^{3}, Y u$ Yang, $M^{4}$, Rakhi P. Naik, MD, MHS ${ }^{5}$, Amit Patki, MS ${ }^{6}$, Lydia H. Pecker, MD , Bryan T. Mott, $\mathrm{PhD}^{7}$, Neil A. Zakai, MD, MSc ${ }^{8,9}$, Cheryl A. Winkler, $\mathrm{PhD}^{10}$, Jeffrey B. Kopp, $\mathrm{MD}^{11}$, Leslie A. Lange, $\mathrm{PhD}^{12}$, Marguerite R. Irvin, PhD, $\mathrm{MS}^{13}$, Orlando M. Gutierrez, MD, MMSc ${ }^{13,14}$, Mary Cushman, MD, MSc ${ }^{8,9}$, Hans C. Ackerman, MD, DPhil, MSc ${ }^{1}$

${ }^{1}$ Laboratory of Malaria and Vector Research, National Institute of Allergy and Infectious Diseases, National Institutes of Health, Bethesda, MD; ${ }^{2}$ Pulmonary Branch, National Heart, Lung, and Blood Institute, Bethesda, MD; ${ }^{3}$ Office of Biostatistics Research, National Heart, Lung, and Blood Institute, Bethesda, MD; ${ }^{4}$ Division of Blood Diseases and Resources, National Heart, Lung, and Blood Institute, Rockville, MD; ${ }^{5}$ Division of Hematology, Department of Medicine, Johns Hopkins University School of Medicine, Baltimore, Maryland; ${ }^{6}$ Department of Biostatistics, University of Alabama at Birmingham, Birmingham, Alabama; ${ }^{7}$ University of Alabama at Birmingham School of Medicine, Birmingham, Alabama; ${ }^{8}$ Department of Medicine, Larner College of Medicine at the University of Vermont, Burlington, Vermont; ${ }^{9}$ Department of Pathology \& Laboratory Medicine, Larner College of Medicine at the University of Vermont, Burlington, Vermont; ${ }^{10}$ Basic Research Program, National Cancer Institute, Frederick National Laboratory for Cancer Research, Frederick, Maryland; ${ }^{11}$ Kidney Diseases Branch, National Institute of Diabetes and Digestive and Kidney Diseases, National Institutes of Health, Bethesda, Maryland; ${ }^{12}$ Division of Biomedical Informatics and Personalized Medicine, Department of Medicine, University of Colorado, Denver, CO; ${ }^{13}$ Department of Epidemiology, University of Alabama at Birmingham, Birmingham, Alabama; ${ }^{14}$ Department of Medicine, University of Alabama at Birmingham, Birmingham, Alabama

Keywords: alpha globin; alpha thalassemia; kidney disease; hemoglobin; nitric oxide

Word count: 3,707

Figure and tables: 5

Running title: Alpha globin and kidney disease

Corresponding author:

Dr. A. Parker Ruhl, MD, MHS

Building 10-Clinical Research Center, Rm. B3-4207

10 Center Dr., Bethesda MD, 20892-1684

parker.ruhl@nih.gov

Tel: 240-669-5776

Fax: 301-480-0590 
medRxiv preprint doi: https://doi.org/10.1101/2021.04.01.21254397; this version posted April 5, 2021. The copyright holder for this preprint (which was not certified by peer review) is the author/funder, who has granted medRxiv a license to display the preprint in perpetuity. This article is a US Government work. It is not subject to copyright under 17 USC 105 and is also made available for use under a CCO license.

\section{ABSTRACT}

Background: Alpha globin gene $(H B A)$ copy number is variable among people of African descent. HBA limits endothelial nitric oxide signaling and variation in gene copy number could modify kidney disease risk in this population.

Objective: To examine the association of $H B A$ copy number with chronic kidney disease (CKD) and end-stage kidney disease (ESKD). We hypothesized that higher HBA copy number would be associated with greater CKD prevalence and ESKD incidence.

Design: Prospective, longitudinal cohort from the REasons for Geographic and Racial Differences in Stroke (REGARDS) study which enrolled participants from 2003 through 2007 and conducted follow-up through June 2014. Data were analyzed from January 2018 through January 2021.

Setting: Community-dwelling participants enrolled throughout the contiguous United States

Participants: Black Americans age 45 years and older

Measurements: HBA copy number was measured using droplet-digital PCR on genomic DNA; copy number ranged from 2 to $\geq 5$ copies. The prevalence ratio $(P R)$ of $C K D$ and relative risk (RR) of incident reduced estimated glomerular filtration rate (eGFR) were calculated using modified Poisson multivariable regression employing a log-linear effect of $H B A$ allele count. The hazard ratio (HR) of incident ESKD was calculated using Cox proportional hazards multivariable regression. 
medRxiv preprint doi: https://doi.org/10.1101/2021.04.01.21254397; this version posted April 5, 2021. The copyright holder for this preprint (which was not certified by peer review) is the author/funder, who has granted medRxiv a license to display the preprint in perpetuity. This article is a US Government work. It is not subject to copyright under 17 USC 105 and is also made available for use under a CCO license.

Results: Among 9,918 participants, $H B A$ gene copy number frequencies were $4 \%, 28 \%, 67 \%$, and $1 \%$ for $2,3,4$, and $\geq 5$ copies, respectively. After adjusting for demographic, clinical, and genetic risk factors, each additional copy of $H B A$ was associated with $14 \%$ greater prevalence of $\mathrm{CKD}(\mathrm{PR}=1.14,95 \% \mathrm{Cl} 1.07$ to $1.21 ; P<0.0001)$. While there was no significant association with incident reduced eGFR $(R R=1.06,95 \% C l 0.94$ to $1.18 ; p=0.36)$, the hazard of incident ESKD was $28 \%$ higher for each additional copy of $H B A(H R=1.28,95 \% \mathrm{Cl} 1.01$ to $1.61 ; P=0.04)$

Limitations: This study did not identify the mechanism by which $H B A$ copy number modifies kidney disease risk. This study focused on Black Americans, a population with a high frequency of the $3.7 \mathrm{~kb}$ gene deletion; it is unknown whether $H B A$ modifies kidney disease risk in other populations with the $3.7 \mathrm{~kb}$ deletion.

Conclusions: Increasing HBA copy number was associated with greater prevalent CKD and incident ESKD in a national longitudinal study of Black Americans.

Funding Source: National Institutes of Health 
medRxiv preprint doi: https://doi.org/10.1101/2021.04.01.21254397; this version posted April 5, 2021. The copyright holder for this preprint

(which was not certified by peer review) is the author/funder, who has granted medRxiv a license to display the preprint in perpetuity.

This article is a US Government work. It is not subject to copyright under 17 USC 105 and is also made available for use under a CCO license.

\section{INTRODUCTION}

Black Americans develop kidney disease at a younger age than other Americans and are three times more likely to develop end-stage kidney disease (ESKD), even after accounting for socioeconomic factors and comorbid medical conditions. ${ }^{1-6}$ DNA sequence variants that increase the risk of kidney disease, such as those in $H B B$ (sickle cell trait) ${ }^{7,8}$ and $A P O L 1^{9-11}$ are more common among Black Americans, yet only partly explain the racial disparity in kidney disease. The evaluation of genetic risk factors for diseases common in minority populations in the United States remains a high priority. However, Blacks and other minority populations are underrepresented in many large-scale longitudinal US population studies hindering genetic investigations. $^{12,13}$

Basic science ${ }^{14-17}$ and clinical studies ${ }^{18,19}$ have identified nitric oxide signaling as important in protection against and recovery from ischemic or oxidative injury to the kidney; however, to date there have been few clear associations with genetic variants in nitric oxide signaling pathways in the kidney. ${ }^{20-23}$ Alpha globin, encoded by the tandem duplicated $H B A 1$ and $H B A 2$ genes on human chromosome 16 , has been proposed to function as a regulator of nitric oxide signaling in the endothelial cells of small resistance arteries. ${ }^{24}$ Genetic or pharmacologic disruption of alpha globin or its stabilizing protein leads to enhanced nitric oxide signaling and decreased vasoconstriction in response to alpha-adrenergic stimuli, ${ }^{25-27}$ potentially conferring protection against kidney injury. The genes encoding alpha globin are highly polymorphic worldwide and a 3.7 kilobase insertion/deletion variant is common among Black Americans. This deletion spans parts of the $H B A 2$ and $H B A 1$ genes and reduces the functional gene copy number by one; leading to a decrease in $H B A$ gene expression in red cell precursors. ${ }^{28}$ Due to the unique challenges of genotyping this structural variant, it has been omitted from genome-wide association studies. We hypothesized that higher HBA copy number would be associated with greater risk of prevalent chronic kidney disease (CKD), incident reduced eGFR, and incident ESKD among Black Americans. 
medRxiv preprint doi: https://doi.org/10.1101/2021.04.01.21254397; this version posted April 5, 2021. The copyright holder for this preprint

(which was not certified by peer review) is the author/funder, who has granted medRxiv a license to display the preprint in perpetuity.

This article is a US Government work. It is not subject to copyright under 17 USC 105 and is also made available for use under a CCO license.

\section{METHODS}

\section{Study Design}

The REasons for Geographic and Racial Differences in Stroke (REGARDS) study is a longitudinal cohort study designed to determine the reasons for racial disparities in stroke and cognitive decline in Black and White Americans aged $\geq 45$ years. ${ }^{29}$ REGARDS enrolled 30,239 community-dwelling participants from the 48 contiguous United States from 2003 to 2007. A total of 12,514 (41\%) participants were Black, and $56 \%$ were from states considered to be in the stroke belt, where stroke incidence in the United States is highest. Exclusion criteria included self-reported race other than Black / African-American or White, residence in or on the waiting list for a nursing home, active cancer within the past year, or inability to communicate in English.

Baseline variables were collected via standardized computer-assisted telephone interview, self-administered questionnaire, and in-home physical examination. ${ }^{29,30}$ Trained personnel administered computer-assisted telephone interviews to collect study participant age, sex, region of residence, insurance status, education level, income, and reports of physiciandiagnosed comorbid conditions. Trained personnel conducted in-home examinations to measure height, weight, and blood pressure (BP); collect blood and urine specimens; and review medication bottles. Baseline measurements were repeated in some participants during a second in-home visit conducted a median $\left(25^{\text {th }}, 75^{\text {th }}\right.$ percentile $)$ of $9.5(8.7,9.9)$ years after baseline.

All participants provided oral and written informed consent. The REGARDS study was approved by participating center Institutional Review Boards. All self-reported Black participants consenting to genetic research were eligible to participate in this study. Participants were excluded if they had hemoglobin SS $(n=5)$, SC $(n=1)$ or CC $(n=6)$, or had ESKD at enrollment $(n=81)$ (Figure 1). This study followed the Strengthening the Reporting of Observational Studies in Epidemiology (STROBE) reporting guideline. 
medRxiv preprint doi: https://doi.org/10.1101/2021.04.01.21254397; this version posted April 5, 2021. The copyright holder for this preprint (which was not certified by peer review) is the author/funder, who has granted medRxiv a license to display the preprint in perpetuity. This article is a US Government work. It is not subject to copyright under 17 USC 105 and is also made available for use under a CCO license.

\section{Main exposure variable}

$H B A$ copy number was evaluated as a numerical variable with values of $2,3,4,5$, or 6 as determined by droplet digital PCR (ddPCR) analysis of genomic DNA. The ddPCR copy number assay targeted a unique sequence within the $3.7 \mathrm{~kb}$ insertion/deletion polymorphism. We determined copy number of this target relative to a reference gene EIF2C1. Twodimensional clusters of droplet counts for target and reference genes were manually gated using Quantasoft (Bio-Rad) per the manufacturer's protocols. Droplet counts, copy number variant (CNV) values, and 95\% Cls for CNV were extracted, visualized, and genotype was assigned using custom scripts in the $\mathrm{R}$ computing environment without user intervention (see Appendix).

\section{Outcome measures}

Prevalent CKD was defined by a urine albumin to creatinine ratio $\geq 30 \mathrm{mg} / \mathrm{g}$ or an estimated glomerular filtration rate $(\mathrm{eGFR})<60 \mathrm{~mL} / \mathrm{min} / 1.73 \mathrm{~m}^{2}$ at baseline. The Chronic Kidney Disease Epidemiology Consortium equation was used to estimate GFR from serum creatinine concentrations. Incident reduced eGFR was defined by an eGFR $<60 \mathrm{~mL} / \mathrm{min}$ at the follow-up in-home visit and greater than 40\% decline in eGFR from baseline, among those who had eGFR $\geq 60 \mathrm{~mL} / \mathrm{min}$ at baseline. The incident reduced eGFR analysis was limited to those participants with available follow-up visit data (Figure 1). Incident ESKD was identified by linkage to United States Renal Data System (USRDS) data through June 30, 2014.

\section{Covariates}

Sickle cell trait and hemoglobin $\mathrm{C}$ genotypes were measured by a TaqMan single nucleotide polymorphism (SNP) genotyping assay (Applied Biosystems/Thermo Fisher Scientific). ${ }^{8}$

Apolipoprotein-L1 (APOL1) high-risk genotype was defined as the presence of two renal risk alleles compared to a reference of less than two high-risk alleles. ${ }^{31,32}$ Systolic (SBP) and 
medRxiv preprint doi: https://doi.org/10.1101/2021.04.01.21254397; this version posted April 5, 2021. The copyright holder for this preprint (which was not certified by peer review) is the author/funder, who has granted medRxiv a license to display the preprint in perpetuity. This article is a US Government work. It is not subject to copyright under 17 USC 105 and is also made available for use under a CCO license.

diastolic blood pressure (DBP) were defined as the average of two measurements performed according to a standardized protocol. ${ }^{33}$ Hypertension was defined as one or more of the following: SBP $\geq 140 \mathrm{mmHg}$ or $\mathrm{DBP} \geq 90 \mathrm{mmHg}$; self-reported current use of medication to control blood pressure; or two or more antihypertensive medications found on medication bottle review during the baseline in-home study visit. Hemoglobin, red blood cell (RBC) count and mean cell volume (MCV) values were measured with an automated hematology analyzer and mean cell hemoglobin $(\mathrm{MCH})$, mean corpuscular hemoglobin concentration (MCHC), and redcell distribution width-coefficient of variation (RDW-CV) calculated using standard formulae. ${ }^{34}$ Diabetes mellitus was defined by a fasting glucose level $\geq 126 \mathrm{mg} / \mathrm{dL}$, a random glucose $\geq 200$ $\mathrm{mg} / \mathrm{dL}$, or use of anti-diabetic medication. Body mass index was calculated from measured height and weight. Smoking status was self-reported and categorized as never, past, or current smoker. Region was defined as three geographic areas: stroke belt buckle (coastal plains of North Carolina, South Carolina, and Georgia), stroke belt (the rest of North Carolina, South Carolina, and Georgia and the entire states of Tennessee, Alabama, Mississippi, Arkansas, and Louisiana), and stroke nonbelt (the remaining contiguous US). Age, sex, race, health insurance (yes or no), highest education level obtained (less than high school, high school, some college, college or more), and annual income ( $\leq \$ 20 \mathrm{~K}, \$ 20-34 \mathrm{~K}, \$ 35-74 \mathrm{~K}, \geq \$ 75 \mathrm{~K})$ were self-reported.

\section{Statistical analysis}

The analytic plan and outcome measure definitions were prespecified and approved by the REGARDS Cohort Study Executive Committee in December 2018.

\section{Unadjusted analyses of participant characteristics by HBA copy number}

For continuous measures of participant characteristics, medians and $25^{\text {th }}$ and $75^{\text {th }}$ percentiles were calculated by $H B A$ copy number. Differences between copy number groups were assessed by Kruskal-Wallis non-parametric analysis of variance. Categorical variables were 
medRxiv preprint doi: https://doi.org/10.1101/2021.04.01.21254397; this version posted April 5, 2021. The copyright holder for this preprint (which was not certified by peer review) is the author/funder, who has granted medRxiv a license to display the preprint in perpetuity. This article is a US Government work. It is not subject to copyright under 17 USC 105 and is also made available for use under a CCO license.

calculated as percentages within each category and differences were assessed by chi-squared tests of association.

\section{Adjusted Analyses of HBA copy number and kidney disease outcome measures}

The primary outcome measure was the presence or absence of prevalent CKD at baseline and the main exposure variable was $H B A$ copy number. In addition, secondary outcome measures for incident reduced eGFR and incident ESKD were evaluated. A modified Poisson regression model with robust variance estimation was used to estimate the prevalence ratio (PR) and 95\% confidence interval $(\mathrm{Cl})$ for $\mathrm{CKD}$ and the relative risk $(\mathrm{RR})$ and $95 \% \mathrm{Cl}$ for incident reduced eGFR. ${ }^{35}$ The models estimated the difference in log-transformed PR or RR for each additional $H B A$ allele. Thirteen known risk factors for kidney disease were included in the multivariable regression models for prevalent CKD, incident reduced eGFR, and incident ESKD (see covariates section above). Incident ESKD hazard ratio $(\mathrm{HR})$ and $95 \% \mathrm{Cl}$ was estimated with a multivariable Cox proportional-hazards model for the time between baseline and date of ESKD onset from USRDS.

\section{Missing data considerations}

Missing data for the outcome measures and explanatory variables were rare $(<0.5 \%)$ with some exceptions, e.g., complete blood count results (Table 1). A multiple imputation approach was employed in all multivariable regression models (see Appendix). ${ }^{36}$

\section{Sensitivity analyses and tests for interaction}

To address the possibility of association by population stratification, we performed a sensitivity analysis including the first ten principal components of ancestry among 7,641 (77\%) participants for whom Infinium Expanded Multi-Ethnic Genotyping Array data were available. 
medRxiv preprint doi: https://doi.org/10.1101/2021.04.01.21254397; this version posted April 5, 2021. The copyright holder for this preprint (which was not certified by peer review) is the author/funder, who has granted medRxiv a license to display the preprint in perpetuity. This article is a US Government work. It is not subject to copyright under 17 USC 105 and is also made available for use under a CCO license.

A pre-specified test for interaction between HBA copy number and SCT on the outcomes of prevalent CKD, incident reduced eGFR, and incident ESKD was performed for the fully adjusted multivariable models. Additionally, pre-specified tests for interaction between $H B A$ copy number and each of the following variables, APOL1, age, sex, and hypertension, were performed on the outcome of prevalent CKD for the fully adjusted multivariable model.

\section{Relationships between the structural variant and flanking SNPS}

To exclude the possibility that the associations with kidney disease risk measured at the structural variant in the $H B A 1$ and $H B A 2$ loci were due to linkage disequilibrium with flanking SNPs, we analyzed SNP genotypes available on 8,841 participants from the Infinium Expanded Multi-Ethnic Genotyping Array. Pairwise linkage disequilibrium was calculated between the -3.7 kb structural variant and each of 13,549 SNPs in the first $1 \mathrm{Mb}$ of chromosome 16 using the $r^{2}$ statistic in the $R$ ( $v$ 3.6.2) package genetics. Associations between individual SNPs and CKD prevalence were calculated using PLINK ( $v$ 1.9) in a regression model that included age, sex, and the first 4 prinicipal components of ancestry. The threshold for significance for a $1 \mathrm{Mb}$ segment of the genome was estimated to be $p<1.5 \times 10^{-4}$ based on the threshold for genomewide significance $\left(p<5 \times 10^{-8}\right)$ divided by the fraction of the genome (1 Mb / 3,097 Mb) analyzed. $^{38}$

\section{Population preventable fraction}

To estimate the fraction of kidney disease prevented by the protective genotypes of $H B A$ copy numbers 2 or 3 among Black Americans, we calculated the population preventable fraction and the upper and lower bounds of the $95 \% \mathrm{Cl}$ for the fully adjusted models (further methods in the Appendix). 
medRxiv preprint doi: https://doi.org/10.1101/2021.04.01.21254397; this version posted April 5, 2021. The copyright holder for this preprint

(which was not certified by peer review) is the author/funder, who has granted medRxiv a license to display the preprint in perpetuity.

This article is a US Government work. It is not subject to copyright under 17 USC 105 and is also made available for use under a CCO license.

The authors conducted the study, analyzed the data, and wrote the manuscript independently of the funding source.

\section{RESULTS}

\section{HBA copy number variation}

HBA copy number was variable among the 9,918 participants who met inclusion and exclusion criteria (Figure 1): 393 participants (4\%) had 2 HBA copies, 2,747 (28\%) had 3 HBA copies, 6,674 (67\%) had 4 HBA copies, 102 (1\%) had 5 HBA copies, and $2(<1 \%)$ participants had 6 HBA copies (Table 1). CKD prevalence increased with $H B A$ copy number. It was $21 \%$ among those with 2 HBA copies; $25 \%$ among those with 3 copies; $26 \%$ among those with 4 copies; and $36 \%$ among those with $\geq 5$ copies ( $p=0.01$; Table 1 ). Red blood cell parameters differed according to $H B A$ copy number $(p<0.0001)$ : a hypochromic, microcytic anemia was observed in those with 2 copies of $H B A$.

HBA copy number and kidney disease outcome measures

\section{Prevalent chronic kidney disease}

A total of 2,476 (26\%) participants had CKD at baseline. In an unadjusted analysis between $H B A$ copy number and prevalent CKD, each additional copy of $H B A$ was associated with a $9 \%$ greater risk of prevalent CKD (PR = $1.09[95 \% \mathrm{Cl} 1.02,1.15 ; \mathrm{p}=0.009])$. After adjusting for 13 CKD risk factors selected a priori, each additional copy of $H B A$ was associated with a $14 \%$ greater prevalence of CKD (PR = $1.14[95 \% \mathrm{Cl} 1.07-1.21 ; \mathrm{p}<0.0001]) ;$ Table 2 and Appendix Figure 1. 
medRxiv preprint doi: https://doi.org/10.1101/2021.04.01.21254397; this version posted April 5, 2021. The copyright holder for this preprint

(which was not certified by peer review) is the author/funder, who has granted medRxiv a license to display the preprint in perpetuity.

This article is a US Government work. It is not subject to copyright under 17 USC 105 and is also made available for use under a CCO license.

Data were available for 3,736 participants who were evaluated at a second in-home visit (Figure

1). A total of $656(17.6 \%)$ developed incident reduced eGFR over a median $\left(25^{\text {th }}, 75^{\text {th }}\right.$

percentile) of $9.5(8.7,9.9)$ years. In an unadjusted analysis there was no association between

$H B A$ copy number and incident reduced eGFR $(R R=1.01[95 \% \mathrm{Cl} 0.90-1.14 ; \mathrm{p}=0.82])$.

After adjusting for relevant risk factors, there was no association between $H B A$ copy number

and incident reduced eGFR $(R R=1.06[95 \% \mathrm{Cl} 0.94-1.18 ; p=0.36]$ Table 3).

Incident end-stage kidney disease

Out of 9,707 eligible participants for the ESKD analysis, 234 participants developed ESKD over a median $\left(25^{\text {th }}, 75^{\text {th }}\right.$ percentile $)$ of $10.1(5.5,12.5)$ years of follow-up. In an unadjusted analysis there was no significant association between $H B A$ copy number and the hazard of incident $\operatorname{ESKD}(H R=1.02[95 \% \mathrm{Cl} 0.82-1.28 ; \mathrm{p}=0.84])$. In contrast, an analysis adjusted for 13 risk factors selected a priori found that each additional copy of $H B A$ was associated with a $28 \%$ increase in the hazard of incident ESKD $(H R=1.28[95 \% \mathrm{Cl} 1.01-1.61 ; p=0.04]$ Table 4).

\section{Sensitivity analyses and tests of interaction}

The point estimates of the associations between HBA copy number and the outcomes of prevalent CKD, incident reduced eGFR, and incident ESKD were not substantially changed and remained significant for both prevalent CKD and incident ESKD after adjustment for the first ten principal components of ancestry (Appendix Table 1). There was no interaction between $H B A$ copy number and SCT for the outcomes of prevalent CKD, incident reduced eGFR, or incident ESKD (Appendix Table 2), nor was there an interaction between HBA copy number and each of age, sex, hypertension, or APOL1 on the outcome of prevalent CKD (Appendix Table 3). The pvalue of each cross-product interaction term was $\geq 0.20$ in the fully-adjusted models. 
medRxiv preprint doi: https://doi.org/10.1101/2021.04.01.21254397; this version posted April 5, 2021. The copyright holder for this preprint (which was not certified by peer review) is the author/funder, who has granted medRxiv a license to display the preprint in perpetuity. This article is a US Government work. It is not subject to copyright under 17 USC 105 and is also made available for use under a CCO license.

To assess whether associations with $H B A$ copy number could be attributed to sequence variants flanking the $H B A 1$ and $H B A 2$ genes, we examined pairwise linkage disequilibrium between the $-3.7 \mathrm{~kb}$ structural variant and 13,549 single nucleotide polymorphisms (SNPs) within the first $1 \mathrm{Mb}$ of the chromosome. Pairwise linkage disequilibrium was weak between the structural variant and each SNP; the maximum $r^{2}$ value was 0.25 and most SNPs had $r^{2}$ values close to zero (Appendix Figure $2 \mathrm{~A}, \mathrm{~B}$ ). Each SNP was tested for association with prevalent CKD. None of the SNPs reached the threshold for significance for a $1 \mathrm{Mb}$ genome region (Appendix Figures 2 C,D), suggesting that the association between the structural variant and kidney disease risk was not due to linkage disequilibrium with SNPs in flanking gene regions.

\section{Population preventable fraction}

To assess the fraction of kidney disease prevented by the protective 2- and 3-copy $H B A$ genotypes, we estimated the population preventable fraction. The 2- and 3-copy $H B A$ genotypes prevent $4.3 \%(95 \% \mathrm{Cl} 2.1-6.5)$ of prevalent CKD and $11.4 \%(95 \% \mathrm{Cl}: 2.2-20.6)$ of incident ESKD among Black Americans (see Appendix).

\section{DISCUSSION}

In this national longitudinal cohort study of Black Americans, each additional HBA copy was associated with a $14 \%$ greater prevalence of CKD and a $28 \%$ greater risk of incident ESKD after adjustment for established genetic, biomedical, demographic, and social risk factors. Kidney disease risk increased with higher $H B A$ copy number, suggesting that the level of $H B A$ gene expression, rather than a specific allele, was responsible for this genetic association. These findings support the hypothesis that higher HBA copy number is associated with greater risk of kidney disease among Black Americans. Moreover, the protective 2- and 3-copy HBA genotypes (i.e., homozygotes and heterozygotes for the $3.7 \mathrm{~kb}$ gene deletion) were estimated to 
medRxiv preprint doi: https://doi.org/10.1101/2021.04.01.21254397; this version posted April 5, 2021. The copyright holder for this preprint (which was not certified by peer review) is the author/funder, who has granted medRxiv a license to display the preprint in perpetuity. This article is a US Government work. It is not subject to copyright under 17 USC 105 and is also made available for use under a CCO license.

prevent approximately $4 \%$ of prevalent CKD and $11 \%$ of incident ESKD among Black Americans.

$H B A$ copy number was associated with both the risk of prevalent CKD at baseline and the incidence of ESKD; HBA copy number was not associated with incident reduced eGFR. To be included in the incident reduced eGFR analysis, participants had to undergo a second inhome visit. Participants in the group providing second in-home visit data appeared healthier and of a higher socioeconomic status at baseline than those who did not take part in the second in-home visit. Together, the reduced disease severity, smaller sample size available for analysis $(n=3,736)$, and the stringent pre-specified definition of reduced eGFR ( $40 \%$ decrease), may have reduced the power to detect an effect of $H B A$ copy number on this secondary endpoint.

Genetic associations can arise from population structure, i.e., underlying differences in genetic ancestry between those who develop kidney disease and those who do not. To address this, we performed a pre-specified sensitivity analysis that included principal components of ancestry and confirmed the association between HBA copy number and prevalent CKD was not due to population structure. We evaluated a pre-specified additive relationship between $H B A$ copy number and kidney disease risk because hematologic observations demonstrate a quantitative relationship between HBA copy number and alpha globin protein abundance. ${ }^{45,46}$ The association with $H B A$ copy number was unlikely due to linkage disequilibrium with sequence variants in nearby genes, given the established relationship between $H B A$ copy number and functional gene expression; the rapid decline of linkage disequilibrium away from the $H B A$ loci; ${ }^{47}$ and the additive mode of inheritance (i.e., a dose-response relationship between $H B A$ copy number and CKD risk) which transcends any single $H B A$ allele. Nevertheless, we (i) measured pairwise linkage disequilibrium between the structural variant and SNPs directly and (ii) measured association between each SNP and prevalent CKD. We found no SNPs that could explain the observed association between HBA copy number and kidney disease risk. 
medRxiv preprint doi: https://doi.org/10.1101/2021.04.01.21254397; this version posted April 5, 2021. The copyright holder for this preprint

(which was not certified by peer review) is the author/funder, who has granted medRxiv a license to display the preprint in perpetuity.

This article is a US Government work. It is not subject to copyright under 17 USC 105 and is also made available for use under a CCO license.

Changes in the level of $H B A$ gene expression determined by functional gene copy number remains the most plausible genetic mechanism responsible for the associations with kidney disease risk.

Alpha thalassemia is known to modify the risk of sickle cell disease nephropathy ${ }^{42,43}$; therefore, we considered whether the reduction in HBA copy number mitigated the impact of sickle cell trait on kidney disease risk. We found the association between $H B A$ copy number and kidney disease risk to be independent of sickle cell trait, and there was no interaction between $H B A$ copy number and sickle cell trait on kidney disease outcomes in the pre-specified analysis. A previous study reported that $H B A$ genotype modified CKD risk among those with sickle cell trait, but they found no association between $H B A$ and CKD in the general population. ${ }^{44}$ The current study differs substantially from the prior report in the following ways: (1) ddPCR was used to quantify HBA copy number from 2 to 6; (2) a prespecified log-linear effect of $H B A$ copy number was employed; (3) the current study population was more than three times larger, with older individuals and a higher prevalence of CKD; (4) additional established social, demographic, clinical factors were included in the current analysis. Together, the precise estimation of copy number, increased sample size, and additional covariates may have increased the power to detect an association between HBA copy number and kidney disease risk in the current study.

There are several potential mechanisms through which HBA copy number variation could modify kidney disease risk in a general population of Black Americans. One such mechanism is through decreased erythroid expression of $H B A$ leading to anemia, a risk factor for kidney disease. However, $H B A$ variants associated with protection against kidney disease tended to be associated with lower, not higher, hemoglobin levels. Moreover, the associations between $H B A$ copy number and kidney disease risk remained significant when adjusted for hemoglobin level. We considered whether anemia associated with CKD could have contributed to overestimation of the effect of HBA copy number in the prevalent CKD model. In a post-hoc 
medRxiv preprint doi: https://doi.org/10.1101/2021.04.01.21254397; this version posted April 5, 2021. The copyright holder for this preprint (which was not certified by peer review) is the author/funder, who has granted medRxiv a license to display the preprint in perpetuity. This article is a US Government work. It is not subject to copyright under 17 USC 105 and is also made available for use under a CCO license.

sensitivity analysis omitting hemoglobin, there was no substantial change in the prevalence ratio for CKD (Appendix Table 4 in the Appendix). Red cell microcytosis associated with lower $H B A$ copy numbers could potentially confer protection against kidney disease through improved blood rheology; ${ }^{39}$ however, this mechanism does not explain the increased risk associated with higher HBA copy numbers $(5,6)$ that have normal MCV. Thus, a clear hematological mechanism explaining the association between $H B A$ copy number and kidney disease risk is not apparent.

Alpha globin is expressed not only in red cell precursors, but also in the endothelium of resistance arteries where it regulates nitric oxide signaling. ${ }^{24}$ Genetic deletion of $H b a$ or its stabilizing protein Ahsp altered small artery vasoreactivity in mice-specifically reducing vasoconstriction to alpha-adrenergic stimuli in a NOS-dependent manner. ${ }^{24,27}$ Pharmacological disruption of the alpha globin/eNOS complex in endothelial cells increased nitric oxide release and led to a fall in blood pressure in both normal and hypertensive mice. ${ }^{25,40}$ We speculate that decreased alpha globin gene expression in individuals with decreased HBA copy number could lead to similar increases in endothelial nitric oxide signaling in human arteries and decreased vasoconstriction in response to sympathetic nervous system activity. This could confer protection against kidney disease in a manner consistent with the protective role of increased nitric oxide signaling in experimental and human clinical studies of kidney injury. ${ }^{19,15,16,18,41}$

This study has strengths and limitations. The REGARDS study is one of the largest available cohorts of Black Americans, and has clearly-defined kidney disease outcome measures and as well as data on social, biomedical, and genetic factors. This allows adjustment for established kidney disease risk factors when estimating risk. We pre-specified the analysis plan to reduce the chance of spurious associations. We employed a robust and quantitative ddPCR method to genotype the insertion/deletion polymorphism and gene triplication in the HBA loci. We evaluated genetic risk factors for CKD specific to Black individuals, SCT and high-risk $A P O L 1$ status, and determined that $H B A$ copy number was 
medRxiv preprint doi: https://doi.org/10.1101/2021.04.01.21254397; this version posted April 5, 2021. The copyright holder for this preprint (which was not certified by peer review) is the author/funder, who has granted medRxiv a license to display the preprint in perpetuity. This article is a US Government work. It is not subject to copyright under 17 USC 105 and is also made available for use under a CCO license.

associated with kidney disease independently of these factors. This analysis focused on a Black American population, in which the $3.7 \mathrm{~kb}$ gene deletion is common. These findings should not be extrapolated to other populations in which the $3.7 \mathrm{~kb}$ deletion is found.

The major genetic variants that determine kidney disease risk among Blacks arose in Africa as mutations conferring resistance to infectious diseases: $H B A$ and $H B B$ variants (like those that cause alpha thalassemia and sickle cell trait) confer protection against malaria while APOL1 variants protect against trypanosomiasis, or African sleeping sickness. ${ }^{48-50}$ In contrast to the variant alleles of $H B B$ and $A P O L 1$, which confer protection against infectious diseases at the cost of increased kidney disease risk, the $3.7 \mathrm{~kb}$ deletion in $H B A$ is associated with protection against both malaria and kidney disease.

In conclusion, we report that higher HBA copy number was independently associated with greater CKD prevalence and ESKD incidence after accounting for known clinical, demographic and genetic risk factors in this national longitudinal study of Black Americans. The high frequency of the $H B A$ gene deletion found in Black Americans may act to reduce the overall burden of kidney disease in this population. 
medRxiv preprint doi: https://doi.org/10.1101/2021.04.01.21254397; this version posted April 5, 2021. The copyright holder for this preprint

(which was not certified by peer review) is the author/funder, who has granted medRxiv a license to display the preprint in perpetuity.

This article is a US Government work. It is not subject to copyright under 17 USC 105 and is also made available for use under a CCO license.

\section{ACKNOWLEDGEMENTS}

This is an ancillary study supported by cooperative agreement U01 NS041588 co-funded by the National Institute of Neurological Disorders and Stroke (NINDS) and the National Institute on Aging (NIA), National Institutes of Health, Department of Health and Human Service. This research was supported in part by the Divisions of Intramural Research, National Institute of Allergy and Infectious Diseases project Al001150 (A.P.R., H.C.A), National Heart, Lung, and Blood Institute (NHLBI) project HL006196 (A.P.R., Y.Y., H.C.A.). This work was also funded in part by the National Cancer Institute (NCI) Intramural Research Program (C.A.W) and under contract HHSN26120080001E, the National Institute of Diabetes and Digestive and Kidney Diseases (NIDDK) Z01 DK04312 (J.B.K.), and the NHLBI grants K08HL12510 (R.P.N.) and K08HL096841 (N.A.Z.). The content is solely the responsibility of the authors and does not necessarily represent the official views of the NINDS, NIA, NIAID, NCI, NIDDK, or NHLBI. The content of this publication does not necessarily reflect the view or policy of the Department of Health and Human Services, nor does mention of trade names, commercial products or organizations imply endorsement by the government. Some of the data reported here have been supplied by the United States Renal Data System (USRDS). The interpretation and reporting of these data are the responsibility of the author(s) and in no way should be seen as an official policy or interpretation of the U.S. government. The authors thank the investigators, staff, and participants of the REGARDS study for their valuable contributions. A full list of participating REGARDS investigators and institutions can be found at http://www.regardsstudy.org.

\section{Declaration of interests}

Dr. Gutierrez discloses receiving grant funding and consulting fees from Akebia Therapeutics; grant funding and consulting fees from Amgen; grant funding from GlaxoSmithKline; and consulting fees from QED Therapeutics. 
medRxiv preprint doi: https://doi.org/10.1101/2021.04.01.21254397; this version posted April 5, 2021. The copyright holder for this preprint

(which was not certified by peer review) is the author/funder, who has granted medRxiv a license to display the preprint in perpetuity.

This article is a US Government work. It is not subject to copyright under 17 USC 105 and is also made available for use under a CCO license.

\section{REFERENCES}

1. Hsu C, Lin F, Vittinghoff E, Shlipak MG. Racial Differences in the Progression from Chronic Renal Insufficiency to End-Stage Renal Disease in the United States. J Am Soc Nephrol 2003;14(11):2902-7.

2. Tarver-Carr ME. Excess Risk of Chronic Kidney Disease among African-American versus White Subjects in the United States: A Population-Based Study of Potential Explanatory Factors. J Am Soc Nephrol 2002;13(9):2363-70.

3. United States Renal Data System. 2018 USRDS annual data report: Epidemiology of kidney disease in the United States. [Internet]. 2018;Available from: https:Ilusrds.org/adr.aspx

4. Burrows NR, Li Y, Williams DE. Racial and ethnic differences in trends of end-stage renal disease: United States, 1995 to 2005. Adv Chronic Kidney Dis 2008;15(2):147-52.

5. Nally JV. Chronic kidney disease in African Americans: Puzzle pieces are falling into place. Cleve Clin J Med 2017;84(11):855-62.

6. McClellan W. Racial Differences in the Prevalence of Chronic Kidney Disease among Participants in the Reasons for Geographic and Racial Differences in Stroke (REGARDS) Cohort Study. J Am Soc Nephrol 2006;17(6):1710-5.

7. Naik RP, Derebail VK, Grams ME, et al. Association of Sickle Cell Trait With Chronic Kidney Disease and Albuminuria in African Americans. JAMA 2014;312(20):2115-25.

8. Naik RP, Irvin MR, Judd S, et al. Sickle Cell Trait and the Risk of ESRD in Blacks. J Am Soc Nephrol JASN 2017;28(7):2180-7.

9. Genovese G, Friedman DJ, Ross MD, et al. Association of Trypanolytic ApoL1 Variants with Kidney Disease in African Americans. Science 2010;329(5993):841-5.

10. Parsa A, Kao WHL, Xie D, et al. APOL1 risk variants, race, and progression of chronic kidney disease. N Engl J Med 2013;369(23):2183-96.

11. Kopp JB, Winkler CA. Genetics, Genomics, and Precision Medicine in End-Stage Kidney Disease. Semin Nephrol 2018;38(4):317-24.

12. Kannel WB. The Framingham Study: ITS 50-year legacy and future promise. J Atheroscler Thromb 2000;6(2):60-6.

13. Rocca WA, Yawn BP, St Sauver JL, Grossardt BR, Melton LJ. History of the Rochester Epidemiology Project: half a century of medical records linkage in a US population. Mayo Clin Proc 2012;87(12):1202-13.

14. Amador-Martínez I, Pérez-Villalva R, Uribe N, Cortés-González C, Bobadilla NA, BarreraChimal J. Reduced endothelial nitric oxide synthase activation contributes to cardiovascular 
medRxiv preprint doi: https://doi.org/10.1101/2021.04.01.21254397; this version posted April 5, 2021. The copyright holder for this preprint

(which was not certified by peer review) is the author/funder, who has granted medRxiv a license to display the preprint in perpetuity.

This article is a US Government work. It is not subject to copyright under 17 USC 105 and is also made available for use under a CCO license.

injury during chronic kidney disease progression. Am J Physiol Renal Physiol 2019;317(2):F275-85.

15. Emans TW, Janssen BJ, Joles JA, Krediet CTP. Nitric Oxide Synthase Inhibition Induces Renal Medullary Hypoxia in Conscious Rats. J Am Heart Assoc 2018;7(15):e009501.

16. Krishnan SM, Kraehling JR, Eitner F, Bénardeau A, Sandner P. The Impact of the Nitric Oxide (NO)/Soluble Guanylyl Cyclase (sGC) Signaling Cascade on Kidney Health and Disease: A Preclinical Perspective. Int J Mol Sci 2018;19(6):1712.

17. Ortiz PA, Garvin JL. Cardiovascular and renal control in NOS-deficient mouse models. Am J Physiol-Regul Integr Comp Physiol 2003;284(3):R628-38.

18. Lei C, Berra L, Rezoagli E, et al. Nitric Oxide Decreases Acute Kidney Injury and Stage 3 Chronic Kidney Disease after Cardiac Surgery. Am J Respir Crit Care Med 2018;198(10):1279-87.

19. Baylis C. Nitric oxide synthase derangements and hypertension in kidney disease: Curr Opin Nephrol Hypertens 2012;21(1):1-6.

20. Casas JP, Cavalleri GL, Bautista LE, Smeeth L, Humphries SE, Hingorani AD. Endothelial nitric oxide synthase gene polymorphisms and cardiovascular disease: a HuGE review. Am J Epidemiol 2006;164(10):921-35.

21. Zhou T-B, Yin S-S. Association of endothelial nitric oxide synthase Glu298Asp gene polymorphism with the risk of end-stage renal disease. Ren Fail 2013;35(4):573-8.

22. Yun Z, Yu-Ping Y, Zong-Wu T, Yang S, Fang Y, Fang S. Association of endothelial nitric oxide synthase gene polymorphisms with end-stage renal disease: a systematic review and meta-analysis. Ren Fail 2014;36(6):987-93.

23. Chand S, Chue CD, Edwards NC, et al. Endothelial nitric oxide synthase single nucleotide polymorphism and left ventricular function in early chronic kidney disease. PloS One 2015;10(1):e0116160.

24. Straub AC, Lohman AW, Billaud M, et al. Endothelial cell expression of haemoglobin $\alpha$ regulates nitric oxide signalling. Nature 2012;491(7424):473-7.

25. Straub AC, Butcher JT, Billaud M, et al. Hemoglobin $\alpha /$ eNOS Coupling at Myoendothelial Junctions Is Required for Nitric Oxide Scavenging During Vasoconstriction. Arterioscler Thromb Vasc Biol 2014;34(12):2594-600.

26. Keller TCS, Butcher JT, Broseghini-Filho GB, et al. Modulating Vascular Hemodynamics With an Alpha Globin Mimetic Peptide (HbaX). Hypertens Dallas Tex 1979 2016;

27. Lechauve C, Butcher JT, Freiwan A, et al. Endothelial cell $\boldsymbol{\alpha}$-globin and its molecular chaperone $\boldsymbol{\alpha}$-hemoglobin-stabilizing protein regulate arteriolar contractility. J Clin Invest 2018;128(11):5073-82. 
medRxiv preprint doi: https://doi.org/10.1101/2021.04.01.21254397; this version posted April 5, 2021. The copyright holder for this preprint

(which was not certified by peer review) is the author/funder, who has granted medRxiv a license to display the preprint in perpetuity.

This article is a US Government work. It is not subject to copyright under 17 USC 105 and is also made available for use under a CCO license.

28. Dozy AM, Kan YW, Embury SH, et al. alpha-Globin gene organisation in blacks precludes the severe form of alpha-thalassaemia. Nature 1979;280(5723):605-7.

29. Howard VJ, Cushman M, Pulley L, et al. The reasons for geographic and racial differences in stroke study: objectives and design. Neuroepidemiology 2005;25(3).

30. Gillett SR, Boyle RH, Zakai NA, McClure LA, Jenny NS, Cushman M. Validating laboratory results in a national observational cohort study without field centers: the Reasons for Geographic and Racial Differences in Stroke cohort. Clin Biochem 2014;47(16-17):2436.

31. Kopp JB, Nelson GW, Sampath K, et al. APOL1 genetic variants in focal segmental glomerulosclerosis and HIV-associated nephropathy. J Am Soc Nephrol JASN 2011;22(11):2129-37.

32. David VA, Binns-Roemer EA, Winkler CA. Taqman Assay for Genotyping CKD-Associated APOL1 SNP rs60910145: A Cautionary Note. Kidney Int Rep 2019;4(1):184-5.

33. Chobanian AV, Bakris GL, Black HR, et al. The Seventh Report of the Joint National Committee on Prevention, Detection, Evaluation, and Treatment of High Blood Pressure: the JNC 7 report. JAMA 2003;289(19):2560-72.

34. Zakai NA, McClure LA, Prineas R, et al. Correlates of Anemia in American Blacks and Whites The REGARDS Renal Ancillary Study. Am J Epidemiol 2009;169(3):355-64.

35. Zou G. A modified poisson regression approach to prospective studies with binary data. Am J Epidemiol 2004;159(7):702-6.

36. Van Buuren S, Goorthius-Oudshoom K. mice: Multivariate Imputation by Chained Equations in R. J Stat Softw 2011;45(3):1-67.

37. Tran NT, Aslibekyan S, Tiwari HK, et al. PCSK9 variation and association with blood pressure in African Americans: preliminary findings from the HyperGEN and REGARDS studies. Front Genet 2015;6:136.

38. Pe'er I, Yelensky R, Altshuler D, Daly MJ. Estimation of the multiple testing burden for genomewide association studies of nearly all common variants. Genet Epidemiol 2008;32(4):381-5.

39. Lamarre Y, Romana M, Lemonne N, et al. Alpha thalassemia protects sickle cell anemia patients from macro-albuminuria through its effects on red blood cell rheological properties. Clin Hemorheol Microcirc 2014;57(1):63-72.

41. Singh RR, Easton LK, Booth LC, et al. Renal Nitric Oxide Deficiency and Chronic Kidney Disease in Young Sheep Born with a Solitary Functioning Kidney. Sci Rep 2016;6:26777. 
medRxiv preprint doi: https://doi.org/10.1101/2021.04.01.21254397; this version posted April 5, 2021. The copyright holder for this preprint

(which was not certified by peer review) is the author/funder, who has granted medRxiv a license to display the preprint in perpetuity.

This article is a US Government work. It is not subject to copyright under 17 USC 105 and is also made available for use under a CCO license.

42. Guasch A, Zayas CF, Eckman JR, Muralidharan K, Zhang W, Elsas LJ. Evidence that Microdeletions in the $\alpha$ Globin Gene Protect Against the Development of Sickle Cell Glomerulopathy in Humans. J Am Soc Nephrol 1999;10(5):1014-9.

43. Geard A, Pule GD, Chemegni BC, et al. Clinical and genetic predictors of renal dysfunctions in sickle cell anaemia in Cameroon. Br J Haematol 2017;178(4):629-39.

44. Raffield LM, Ulirsch JC, Naik RP, et al. Common $\alpha$-globin variants modify hematologic and other clinical phenotypes in sickle cell trait and disease. PLOS Genet 2018;14(3):e1007293.

45. Liebhaber SA, Kan YW. Differentiation of the mRNA transcripts originating from the alpha 1-and alpha 2-globin loci in normals and alpha-thalassemics. J Clin Invest 1981;68(2):439.

46. Clark B, Shooter C, Smith F, et al. Beta thalassaemia intermedia due to co-inheritance of three unique alpha globin cluster duplications characterised by next generation sequencing analysis. Br J Haematol 2018;180(1):160-4.

47. Danjou F, Zoledziewska M, Sidore C, et al. Genome-wide association analyses based on whole-genome sequencing in Sardinia provide insights into regulation of hemoglobin levels. Nat Genet 2015;47(11):1264-71.

48. Allison AC. Protection afforded by sickle-cell trait against subtertian malareal infection. $\mathrm{Br}$ Med J 1954;1(4857):290-4.

49. Wambua S, Mwangi TW, Kortok M, et al. The Effect of $\alpha+-$ Thalassaemia on the Incidence of Malaria and Other Diseases in Children Living on the Coast of Kenya. PLoS Med 2006;3(5):e158.

50. Vanhamme L, Paturiaux-Hanocq F, Poelvoorde P, et al. Apolipoprotein L-I is the trypanosome lytic factor of human serum. Nature 2003;422(6927):83-7. 
medRxiv preprint doi: https://doi.org/10.1101/2021.04.01.21254397; this version posted April 5, 2021. The copyright holder for this preprint (which was not certified by peer review) is the author/funder, who has granted medRxiv a license to display the preprint in perpetuity.

This article is a US Government work. It is not subject to copyright under 17 USC 105 and is also made available for use under a CCO license.

\section{Figure 1. Cohort flow diagram}

REGARDS= REasons for Geographic and Racial Differences in Stroke Study; $H B B=$ beta globin gene; $H B A=$ alpha globin gene; $C K D=$ chronic kidney disease; $E S K D=$ end-stage kidney disease; eGFR= estimated glomerular filtration rate 
Table 1. Clinical and demographic characteristics according to HBA copy number

\section{HBA copy number}

\begin{tabular}{|c|c|c|c|c|c|c|}
\hline $\begin{array}{l}\text { Participants, } \\
\text { N (\%) }\end{array}$ & $\begin{array}{c}\text { All } \\
\text { Participants } \\
9918(100)\end{array}$ & $393(4)$ & 2747 (28) & $6674(67)$ & $\begin{array}{r}\geq 5^{\star} \\
104(1)\end{array}$ & $\boldsymbol{P}$ value $^{\dagger}$ \\
\hline Age, years & $\begin{array}{c}63.0 \\
(57.0,70.0)\end{array}$ & $\begin{array}{c}64.0 \\
(58.0,70.0)\end{array}$ & $\begin{array}{c}64.0 \\
(57.0,71.0)\end{array}$ & $\begin{array}{c}63.0 \\
(57.0,70.0)\end{array}$ & $\begin{array}{c}66.5 \\
(61.0,72.2)\end{array}$ & 0.01 \\
\hline Female sex, $\mathbf{N}(\%)$ & $6100(62)$ & $246(63)$ & $1681(61)$ & $4115(62)$ & $58(56)$ & 0.61 \\
\hline $\begin{array}{l}\text { Body mass index, } \\
\mathrm{kg} / \mathrm{m}^{2}\end{array}$ & $\begin{array}{c}29.7 \\
(26.2,34.4)\end{array}$ & $\begin{array}{c}30.3 \\
(26.8,31.2)\end{array}$ & $\begin{array}{c}29.9 \\
(26.1,34.4)\end{array}$ & $\begin{array}{c}29.7 \\
(26.1,30.7)\end{array}$ & $\begin{array}{c}30.4 \\
(27.6,30.9)\end{array}$ & 0.22 \\
\hline $\begin{array}{l}\text { Smoking status, } \mathbf{N} \\
(\%)\end{array}$ & & & & & & 0.55 \\
\hline Never & $4478(45)$ & $169(43)$ & $1256(46)$ & 3007 (45) & $46(44)$ & \\
\hline Past & 3675 (37) & $160(41)$ & 1007 (37) & 2464 (37) & $44(42)$ & \\
\hline Current & $1720(17)$ & $61(16)$ & $470(17)$ & $1175(18)$ & $14(13)$ & \\
\hline Region, N (\%) & & & & & & 0.06 \\
\hline Non-Belt & $4936(50)$ & $170(43)$ & $1397(51)$ & $3309(50)$ & $60(58)$ & \\
\hline Belt & 3286 (33) & $142(36)$ & $881(32)$ & 2235 (33) & $28(27)$ & \\
\hline Buckle & 1696 (17) & $81(21)$ & $469(17)$ & $1130(17)$ & $16(15)$ & \\
\hline $\begin{array}{l}\text { Medically insured, } \\
\mathrm{N}(\%)\end{array}$ & $8927(90)$ & $355(91)$ & $2489(91)$ & $5987(90)$ & $96(92)$ & 0.36 \\
\hline $\begin{array}{l}\text { Education level, } \mathbf{N} \\
(\%)\end{array}$ & & & & & & 0.29 \\
\hline $\begin{array}{l}\text { Less than high } \\
\text { school }\end{array}$ & $1939(20)$ & $71(18)$ & $547(20)$ & $1299(19)$ & $22(21)$ & \\
\hline
\end{tabular}


medRxiv preprint doi: https://doi.org/10.1101/2021.04.01.21254397; this version posted April 5, 2021. The copyright holder for this preprint (which was not certified by peer review) is the author/funder, who has granted medRxiv a license to display the preprint in perpetuity. This article is a US Government work. It is not subject to copyright under 17 USC 105 and is also made available for use under a CCO license.

\begin{tabular}{|c|c|c|c|c|c|c|}
\hline $\begin{array}{l}\text { High school } \\
\text { graduate }\end{array}$ & 2730 (28) & $111(28)$ & 787 (29) & $1803(27)$ & $29(28)$ & \\
\hline Some college & 2660 (27) & 105 (27) & 756 (28) & 1770 (27) & $29(28)$ & \\
\hline $\begin{array}{l}\text { College graduate } \\
\text { or more }\end{array}$ & 2577 (26) & $105(27)$ & $655(24)$ & 1793 (27) & $24(23)$ & \\
\hline Income, N (\%) & & & & & & 0.12 \\
\hline$\leq \$ 20 \mathrm{~K}$ & 2654 (30) & $104(30)$ & $746(31)$ & $1773(30)$ & 31 (32) & \\
\hline$\$ 20 K-\$ 34 K$ & $2611(30)$ & $109(31)$ & 725 (30) & $1744(30)$ & $33(34)$ & \\
\hline$\$ 35 K-\$ 74 K$ & 2538 (29) & $106(30)$ & $718(30)$ & $1688(29)$ & $26(27)$ & \\
\hline$\geq \$ 75 \mathrm{~K}$ & $914(10)$ & $32(9)$ & $214(9)$ & $662(11)$ & $\mathrm{N}<11$ & \\
\hline $\begin{array}{l}\text { Hemoglobin, per } \\
\text { g/dL }\end{array}$ & $\begin{array}{c}13.1 \\
(12.2,14.0)\end{array}$ & $\begin{array}{c}12.3 \\
(11.6,13.2)\end{array}$ & $\begin{array}{c}12.9 \\
(12.1,13.8)\end{array}$ & $\begin{array}{c}13.2 \\
(12.4,14.1)\end{array}$ & $\begin{array}{c}13.0 \\
(12.0,14.1)\end{array}$ & $<0.0001$ \\
\hline $\begin{array}{l}\text { RBC count, } \\
\text { million cells } / \mathbf{c m m}\end{array}$ & $\begin{array}{c}4.5 \\
(4.2,4.8)\end{array}$ & $\begin{array}{c}5.2 \\
(4.7,5.6)\end{array}$ & $\begin{array}{c}4.7 \\
(4.3,5.0)\end{array}$ & $\begin{array}{c}4.4 \\
(4.1,4.7)\end{array}$ & $\begin{array}{c}4.4 \\
(4.0,4.7)\end{array}$ & $<0.0001$ \\
\hline MCV, fL & $\begin{array}{c}88.0 \\
(84.0,92.0)\end{array}$ & $\begin{array}{c}74.0 \\
(72.0,77.0)\end{array}$ & $\begin{array}{c}84.0 \\
(82.0,87.0)\end{array}$ & $\begin{array}{c}90.0 \\
(87.0,93.0)\end{array}$ & $\begin{array}{c}88.0 \\
(86.0,92.0)\end{array}$ & $<0.0001$ \\
\hline MCH, pg & $\begin{array}{c}29.6 \\
(27.9,30.9)\end{array}$ & $\begin{array}{c}23.8 \\
(22.8,24.8)\end{array}$ & $\begin{array}{c}27.9 \\
(26.9,29.0\end{array}$ & $\begin{array}{c}30.3 \\
(29.2,31.4)\end{array}$ & $\begin{array}{c}29.9 \\
(29.1,30.9)\end{array}$ & $<0.0001$ \\
\hline MCHC, g/dL & $\begin{array}{c}33.4 \\
(32.9,33.9)\end{array}$ & $\begin{array}{c}32.1 \\
(31.6,32.6)\end{array}$ & $\begin{array}{c}33.0 \\
(32.6,33.5)\end{array}$ & $\begin{array}{c}33.7 \\
(33.2,34.1)\end{array}$ & $\begin{array}{c}33.7 \\
(33.2,34.0)\end{array}$ & $<0.0001$ \\
\hline RDW-CV, \% & $\begin{array}{c}14.0 \\
(13.3,14.8)\end{array}$ & $\begin{array}{c}15.0 \\
(14.4,15.9)\end{array}$ & $\begin{array}{c}14.2 \\
(13.5,15.0)\end{array}$ & $\begin{array}{c}13.8 \\
(13.2,14.6)\end{array}$ & $\begin{array}{c}13.6 \\
(13.2,14.2)\end{array}$ & $<0.0001$ \\
\hline $\begin{array}{l}\text { eGFR }<60 \\
\mathrm{~mL} / \mathrm{min} / 1.73 \mathrm{~m}^{2}, \mathrm{~N} \\
\text { (\%) }\end{array}$ & $1133(11)$ & $37(9)$ & $300(11)$ & 779 (12) & $17(16)$ & 0.16 \\
\hline $\begin{array}{l}\text { Urine albumin to } \\
\text { creatinine ratio } \\
>30 \mathrm{mg} / \mathrm{g}, \mathrm{N}(\%)\end{array}$ & 1794 (19) & 59 (16) & 498 (19) & 1214 (19) & $23(24)$ & 0.23 \\
\hline $\begin{array}{l}\text { Prevalent chronic } \\
\text { kidney disease }^{\ddagger}, N \\
\text { (\%) }\end{array}$ & $2476(26)$ & $80(21)$ & $672(25)$ & $1688(26)$ & $36(36)$ & 0.01 \\
\hline
\end{tabular}


medRxiv preprint doi: https://doi.org/10.1101/2021.04.01.21254397; this version posted April 5, 2021. The copyright holder for this preprint (which was not certified by peer review) is the author/funder, who has granted medRxiv a license to display the preprint in perpetuity. This article is a US Government work. It is not subject to copyright under 17 USC 105 and is also made available for use under a CCO license.

Hypertension, $\mathbf{N}$

(\%)

Diabetes mellitus, N (\%)

Sickle cell trait, $\mathbf{N}$ (\%)

APOL1 high-risk, $\mathrm{N}(\%)$
7314 (77)

2850 (29)

$743(7)$

$1251(13)$
$298(78)$

$103(26)$

$25(6)$

$60(15)$
$4900(76)$

$84(83)$

$818(30)$

$211(8)$

$350(13)$

$1900(29)$

$29(28)$

$H B A=$ alpha globin gene; $\mathrm{N}=$ number; $\mathrm{K}=$ thousand; $\mathrm{RBC}=$ red blood cell; $\mathrm{MCV}=$ mean corpuscular volume; $\mathrm{MCH}=$ mean corpuscular hemoglobin; $\mathrm{MCHC}=$ mean corpuscular hemoglobin concentration; RDW-CV= red cell distribution width-coefficient of variation; eGFR= estimated glomerular filtration rate; $A P O L 1=$ apolipoprotein-L1. Values are median $\left(25^{\text {th }}, 75^{\text {th }}\right.$ percentile) except where otherwise indicated.

${ }^{*} 102$ participants were found to have 5 HBA gene copies and 2 were found to have 6 HBA gene copies; ${ }^{\dagger} \mathrm{P}$ values for tests of differences by $H B A$ copy number generated from the chi-squared test for categorical variables and the Kruskal-Wallis non-parametric ANOVA test for continuous variables; ${ }^{\ddagger}$ Prevalent CKD was defined by a urine albumin to creatinine ratio $\geq 30 \mathrm{mg} / \mathrm{g}$ or an estimated glomerular filtration rate $(\mathrm{eGFR})<60 \mathrm{~mL} / \mathrm{min} / 1.73 \mathrm{~m} 2$ at baseline.

Missing data are as follows: Smoking status ( $n=45,0.5 \%)$; insured $(n=12,0.1 \%)$; education $(n=12,0.1 \%)$; income $(n=1,201$ refused, $12.1 \%)$; eGFR $(n=65,0.7 \%)$; urine albumin creatinine ratio $(n=398,4.0 \%)$; hemoglobin $(n=3,193,32.2 \%)$; RBC count $(n=3,193,32.2 \%)$; MCV $(n=3,200,32.3 \%) ; \operatorname{MCH}(n=3,193,32.2 \%) ; \operatorname{MCHC}(n=3,193,32.2 \%) ; R D W-C V(n=3,206$, $32.3 \%)$; prevalent chronic kidney disease $(n=367,3.7 \%)$; hypertension $(n=389,3.9 \%)$; diabetes mellitus $(n=51,0.5 \%)$; body mass index $(n=73,0.7 \%)$; APOL1 $(n=64,0.6 \%)$. Denominators for 
medRxiv preprint doi: https://doi.org/10.1101/2021.04.01.21254397; this version posted April 5, 2021. The copyright holder for this preprint (which was not certified by peer review) is the author/funder, who has granted medRxiv a license to display the preprint in perpetuity.

This article is a US Government work. It is not subject to copyright under 17 USC 105 and is also made available for use under a CCO license.

percentages in the table are based on the number of non-missing responses. Due to rounding, percentages may not sum to $100 \%$. 
medRxiv preprint doi: https://doi.org/10.1101/2021.04.01.21254397; this version posted April 5, 2021. The copyright holder for this preprint (which was not certified by peer review) is the author/funder, who has granted medRxiv a license to display the preprint in perpetuity. This article is a US Government work. It is not subject to copyright under 17 USC 105 and is also made available for use under a CCO license.

Table 2. Association of HBA gene copy number with prevalent chronic kidney disease analysis adjusted for all listed covariates

\begin{tabular}{|c|c|c|c|}
\hline \multicolumn{4}{|c|}{$\begin{array}{c}\text { Prevalent chronic kidney disease }^{\star} \\
(n=9,918) \\
\text { Modified Poisson }\end{array}$} \\
\hline & PR & $\mathrm{Cl}$ & P value $^{\dagger}$ \\
\hline $\begin{array}{l}\text { HBA copy number, } \\
\text { per gene copy }\end{array}$ & 1.14 & $(1.07-1.21)$ & $<0.0001$ \\
\hline Sickle cell trait & 1.43 & $(1.29-1.59)$ & $<0.0001$ \\
\hline APOL1 high-risk & 1.18 & $(1.07-1.29)$ & 0.0005 \\
\hline $\begin{array}{l}\text { Hemoglobin, per } 1 \\
\text { g/dL }\end{array}$ & 0.89 & $(0.87-0.92)$ & $<0.0001$ \\
\hline Age, per year & 1.03 & $(1.03-1.04)$ & $<0.0001$ \\
\hline Female sex & 0.77 & $(0.71-0.84)$ & $<0.0001$ \\
\hline Body mass index & 1.09 & $(1.05-1.12)$ & $<0.0001$ \\
\hline Hypertension & 1.96 & $(1.72-2.23)$ & $<0.0001$ \\
\hline Diabetes mellitus & 1.64 & $(1.53-1.76)$ & $<0.0001$ \\
\hline \multicolumn{4}{|l|}{ Smoking status } \\
\hline Never (ref) & - & - & \\
\hline Past & 0.98 & $(0.91-1.05)$ & 0.50 \\
\hline Present & 1.29 & $(1.17-1.42)$ & $<0.0001$ \\
\hline Medically Insured & 0.92 & $(0.81-1.04)$ & 0.19 \\
\hline \multicolumn{4}{|l|}{ Region } \\
\hline Non-Belt (ref) & - & - & \\
\hline Belt & 0.97 & $(0.90-1.04)$ & 0.35 \\
\hline Buckle & 1.00 & $(0.91-1.09)$ & 0.99 \\
\hline
\end{tabular}


medRxiv preprint doi: https://doi.org/10.1101/2021.04.01.21254397; this version posted April 5, 2021. The copyright holder for this preprint (which was not certified by peer review) is the author/funder, who has granted medRxiv a license to display the preprint in perpetuity. This article is a US Government work. It is not subject to copyright under 17 USC 105 and is also made available for use under a CCO license.

\section{Education level}

$<$ HS Grad (ref)

HS Grad $\quad 0.94 \quad(0.86-1.03) \quad 0.22$

Some College $\quad 0.99 \quad(0.90-1.10) \quad 0.92$

$\geq$ College Grad $\quad 0.94 \quad(0.85-1.05) \quad 0.29$

\section{Income}

$<\$ 20 K$ (ref)

\$20K - \$34K $\quad 0.97 \quad(0.89-1.06) \quad 0.50$

\$35K - \$74K $\quad 0.91 \quad(0.81-1.01) \quad 0.07$

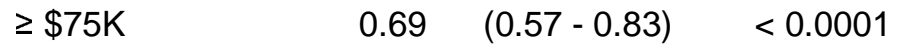

$H B A=$ alpha globin gene; $\mathrm{PR}=$ prevalence ratio; $\mathrm{Cl}=95 \%$ confidence interval; $A P O L 1=$ apolipoprotein-L1; (ref) indicates reference category; $\mathrm{K}=$ thousand.

*Prevalent CKD was defined by a urine albumin to creatinine ratio $\geq 30 \mathrm{mg} / \mathrm{g}$ or an estimated glomerular filtration rate $(\mathrm{eGFR})<60 \mathrm{~mL} / \mathrm{min} / 1.73 \mathrm{~m} 2$ at baseline. ${ }^{\dagger}$ Analysis was performed using modified Poisson multivariable regression model employing a linear effect of $H B A$ allele count on the log of the prevalence ratio. ${ }^{\ddagger}$ Body mass index was scaled by standard deviation. All shown variables in the table were included in multivariable model. Multiple imputations were performed for missing data. The number of participants available for this analysis was 9,918. 
medRxiv preprint doi: https://doi.org/10.1101/2021.04.01.21254397; this version posted April 5, 2021. The copyright holder for this preprint (which was not certified by peer review) is the author/funder, who has granted medRxiv a license to display the preprint in perpetuity. This article is a US Government work. It is not subject to copyright under 17 USC 105 and is also made available for use under a CCO license.

Table 3. Association of $H B A$ gene copy number with incident reduced eGFR - analysis adjusted for all listed covariates

\begin{tabular}{|c|c|c|c|}
\hline \multicolumn{4}{|c|}{$\begin{array}{l}\text { Incident reduced eGFR } \\
\qquad(n=3,736) \\
\text { Modified Poisson }\end{array}$} \\
\hline & $\mathbf{R R}$ & $\mathrm{Cl}$ & $\mathbf{P}_{\text {value }}^{\dagger}$ \\
\hline $\begin{array}{l}\text { HBA copy number, } \\
\text { per gene copy }\end{array}$ & 1.06 & $(0.94-1.18)$ & 0.36 \\
\hline Sickle cell trait & 1.12 & $(0.87-1.43)$ & 0.38 \\
\hline APOL1 high-risk & 1.00 & $(0.81-1.23)$ & 0.98 \\
\hline $\begin{array}{l}\text { Hemoglobin, per } \\
1 \mathrm{~g} / \mathrm{dL}\end{array}$ & 0.91 & $(0.85-0.97)$ & 0.004 \\
\hline Age, per year & 1.04 & $(1.03-1.05)$ & $<0.0001$ \\
\hline Female sex & 1.16 & $(0.97-1.38)$ & 0.11 \\
\hline Body mass index ${ }^{\ddagger}$ & 1.09 & $(1.02-1.17)$ & 0.02 \\
\hline Hypertension & 1.14 & $(0.94-1.38)$ & 0.17 \\
\hline Diabetes mellitus & 1.47 & $(1.27-1.70)$ & $<0.0001$ \\
\hline
\end{tabular}

Smoking status

Never (ref)

Past $\quad 0.98 \quad(0.85-1.14) \quad 0.84$

Present $\quad 1.23 \quad(1.00-1.52) \quad 0.05$

Medically Insured $\quad 0.98 \quad(0.76-1.27) \quad 0.88$

Region

Non-Belt (ref)

Belt $\quad 0.98 \quad(0.84-1.15) \quad 0.80$

$\begin{array}{llll}\text { Buckle } & 1.14 \quad(0.95-1.36) & 0.15\end{array}$ 
medRxiv preprint doi: https://doi.org/10.1101/2021.04.01.21254397; this version posted April 5, 2021. The copyright holder for this preprint (which was not certified by peer review) is the author/funder, who has granted medRxiv a license to display the preprint in perpetuity. This article is a US Government work. It is not subject to copyright under 17 USC 105 and is also made available for use under a CCO license.

\section{Education level}

$<$ HS Grad (ref)

HS Grad $\quad 0.99 \quad(0.80-1.22) \quad 0.90$

Some College $\quad 1.03 \quad(0.82-1.28) \quad 0.82$

$\geq$ College Grad $\quad 0.92 \quad(0.73-1.17) \quad 0.50$

\section{Income}

$<\$ 20 K$ (ref)

$\begin{array}{llll}\$ 20 \mathrm{~K}-\$ 34 \mathrm{~K} & 1.01 \quad(0.84-1.22) & 0.90\end{array}$

$\begin{array}{llll}\$ 35 \mathrm{~K}-\$ 74 \mathrm{~K} & 0.95 \quad(0.77-1.17) & 0.64\end{array}$

$\geq \$ 75 \mathrm{~K} \quad 1.07 \quad(0.81-1.43) \quad 0.62$

$H B A=$ alpha globin gene; eGFR= estimated glomerular filtration rate; $\mathrm{RR}=$ relative risk; $\mathrm{Cl}=95 \%$ confidence interval; $A P O L 1=$ apolipoprotein-L1; (ref) indicates reference category; $\mathrm{K}=$ thousand.

*Incident reduced eGFR was defined by an eGFR $<60 \mathrm{~mL} / \mathrm{min}$ at the follow-up in-home visit and greater than $40 \%$ decline in eGFR from baseline, among those who had eGFR $\geq 60 \mathrm{~mL} / \mathrm{min}$ at baseline. ${ }^{\dagger}$ Analysis was performed using modified Poisson multivariable regression model employing a linear effect of $H B A$ allele count on the log of the relative risk. All shown variables in the table were included in multivariable model. ${ }^{\ddagger}$ Body mass index was scaled by standard deviation. Multiple imputations were performed for missing data. The number of participants available for this analysis was 3,736. $\mathrm{N}=238$ participants were missing eGFR at the second visit. 
medRxiv preprint doi: https://doi.org/10.1101/2021.04.01.21254397; this version posted April 5, 2021. The copyright holder for this preprint (which was not certified by peer review) is the author/funder, who has granted medRxiv a license to display the preprint in perpetuity. This article is a US Government work. It is not subject to copyright under 17 USC 105 and is also made available for use under a CCO license.

Table 4. Association of HBA gene copy number with incident end-stage kidney disease analysis adjusted for all listed covariates

\begin{tabular}{lccc}
\hline \multicolumn{4}{c}{$\begin{array}{c}\text { Incident end-stage kidney disease* } \\
(n=9,707)\end{array}$} \\
$\begin{array}{l}\text { Cox proportional hazards } \\
\text { HR }\end{array}$ & Cl & P value $^{\dagger}$ \\
\hline $\begin{array}{l}\text { HBA copy number, } \\
\text { per geney copy }\end{array}$ & 1.28 & $(1.01-1.61)$ & 0.04 \\
Sickle cell trait & 2.12 & $(1.46-3.09)$ & $<0.0001$ \\
APOL1 high risk & 1.82 & $(1.31-2.53)$ & 0.0003 \\
$\begin{array}{l}\text { Hemoglobin, per } \\
\text { 1g/dL }\end{array}$ & 0.57 & $(0.52-0.63)$ & $<0.0001$ \\
$\begin{array}{l}\text { Age, per year } \\
\text { Female sex }\end{array}$ & 1.00 & $(0.99-1.02)$ & 0.77 \\
Body mass index & 1.08 & $(0.94-1.24)$ & 0.26 \\
Hypertension & 7.51 & $(3.04-18.53)$ & $<0.0001$ \\
Diabetes mellitus & 3.58 & $(2.67-4.80)$ & $<0.0001$
\end{tabular}

Smoking status

Never (ref)

Past $\quad 1.33 \quad(0.98-1.79) \quad 0.06$

Present $\quad 2.15 \quad(1.45-3.17) \quad 0.0001$

Medically Insured $\quad 1.03 \quad(0.63-1.69) \quad 0.89$

Region

Non-Belt (ref)
Belt
$0.84 \quad(0.62-1.14)$
0.28 
medRxiv preprint doi: https://doi.org/10.1101/2021.04.01.21254397; this version posted April 5, 2021. The copyright holder for this preprint (which was not certified by peer review) is the author/funder, who has granted medRxiv a license to display the preprint in perpetuity. This article is a US Government work. It is not subject to copyright under 17 USC 105 and is also made available for use under a CCO license.

Buckle

0.87

$(0.60-1.26)$

0.47

\section{Education level}

$<$ HS Grad (ref)

HS Grad

1.49

$(1.02-2.18)$

0.04

Some College

1.19

$(0.78-1.82)$

0.42

$\geq$ College Grad

1.80

(1.15 - 2.82)

0.010

\section{Income}

$$
<\$ 20 K \text { (ref) }
$$

\$20K - \$34K

0.89

$(0.65-1.23)$

0.49

$\$ 35 \mathrm{~K}-\$ 74 \mathrm{~K}$

0.46

$(0.30-0.71)$

0.0004

$\geq \$ 75 \mathrm{~K}$

0.24

$(0.10-0.59)$

0.002

$\mathrm{HR}=$ hazard ratio; $\mathrm{Cl}=95 \%$ confidence interval; $H B A=$ alpha globin gene; $A P O L 1=$ apolipoprotein-L1; (ref) indicates reference category; $\mathrm{K}=$ thousand.

*Incident end-stage kidney disease was identified by linkage to the United States Renal Data System through June 30, 2014. ${ }^{\dagger}$ Analysis was performed using Cox proportional hazards multivariable regression employing a linear effect of $H B A$ allele count on the log of the hazard ratio. ${ }^{\ddagger}$ Body mass index was scaled by standard deviation. All variables in the table were included in the multivariable model. Multiple imputations were performed for missing data. The number of participants available for this analysis was $n=9,707$. 


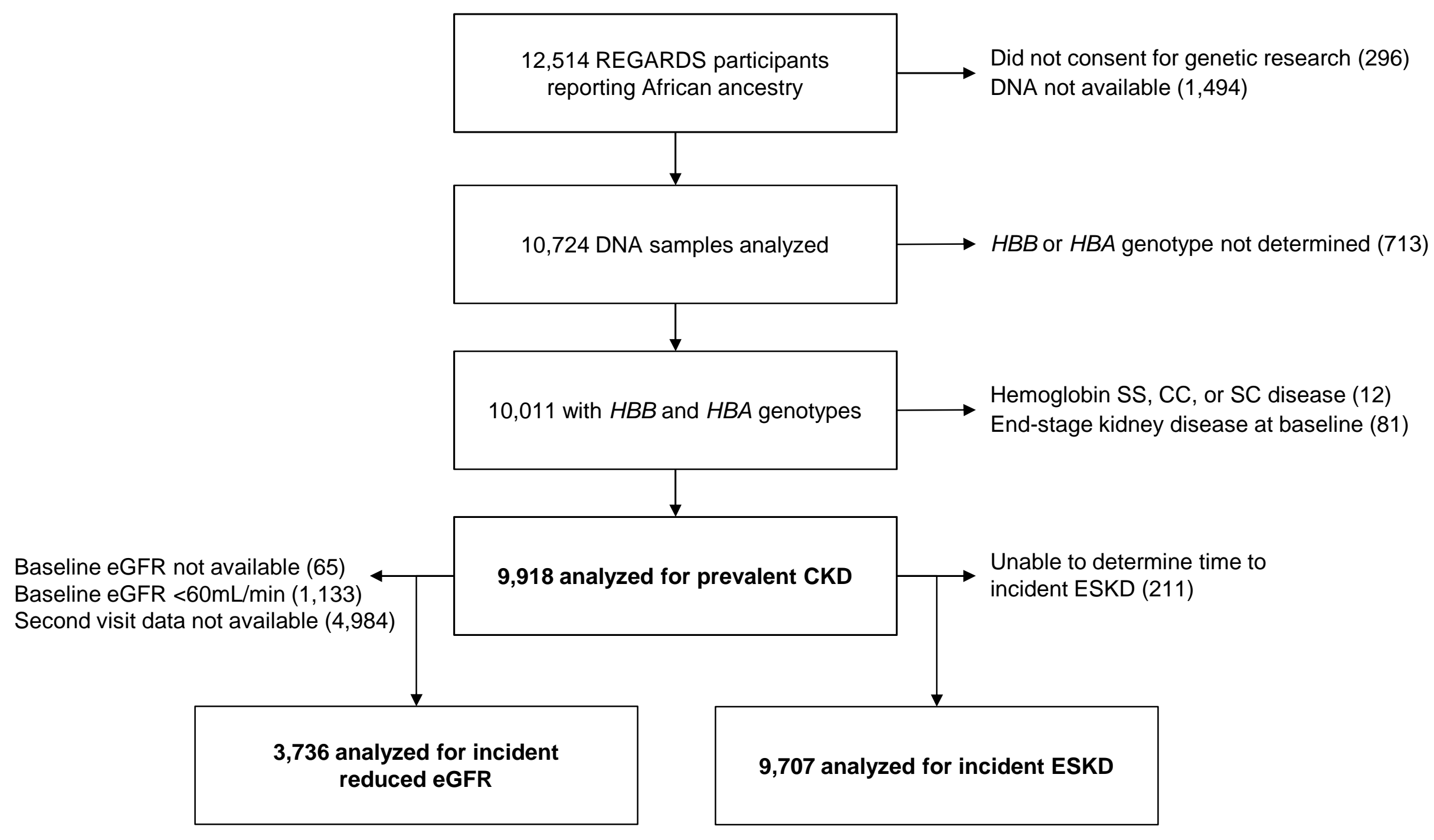

